\title{
ERRATUM
}

Genes \& Development 34: 1089-1105 (2020)

\section{Erratum: A role for alternative splicing in circadian control of exocytosis and glucose homeostasis}

Biliana Marcheva, Mark Perelis, Benjamin J. Weidemann, Akihiko Taguchi, Haopeng Lin, Chiaki Omura, Yumiko Kobayashi, Marsha V. Newman, Eugene J. Wyatt, Elizabeth M. McNally, Jocelyn E. Manning Fox, Heekyung Hong, Archana Shankar, Emily C. Wheeler, Kathryn Moynihan Ramsey, Patrick E. MacDonald, Gene W. Yeo, and Joseph Bass

In the above-mentioned article, the "Competing interest statement" was mistakenly omitted but has now been added to the article online:

"G.W.Y. is cofounder, member of the Board of Directors, on the Scientific Advisory Board, equity holder, and paid consultant for Locanabio and Eclipse BioInnovations. G.W.Y. is a visiting professor at the National University of Singapore. G.W.Y.'s interest(s) have been reviewed and approved by the University of California at San Diego in accordance with its conflict of interest policies. The authors declare no other competing financial interests."

doi: $10.1101 / \operatorname{gad} .348303 .121$ 


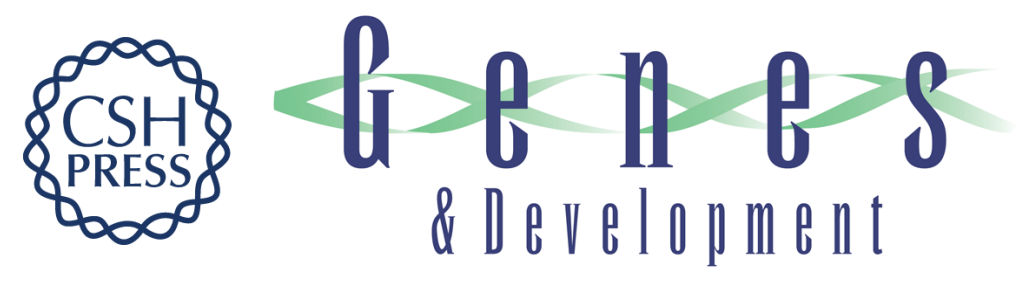

\section{Erratum: A role for alternative splicing in circadian control of exocytosis and glucose homeostasis}

Biliana Marcheva, Mark Perelis, Benjamin J. Weidemann, et al.

Genes Dev. 2021, 35:

Access the most recent version at doi:10.1101/gad.348303.121
Related Content A role for alternative splicing in circadian control of exocytosis and glucose homeostasis
Biliana Marcheva, Mark Perelis, Benjamin J. Weidemann, et al.
Genes Dev. August , 2020 34: 1089-1105

\section{License}
Email Alerting Receive free email alerts when new articles cite this article - sign up in the box at the top Service right corner of the article or click here.

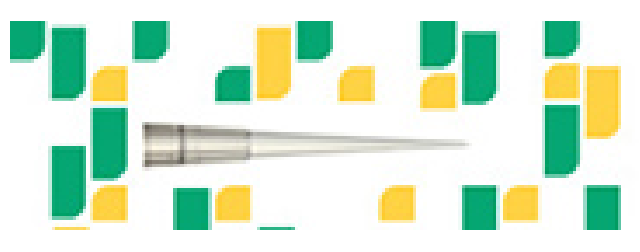

Focused on your science. 